\title{
Application of Extraction and Determination Based on Deep Eutectic Solvents in Different Types of Environmental Samples
}

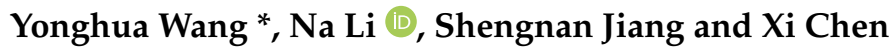 \\ Key Laboratory of Integrated Regulation and Resource Development on Shallow Lake of Ministry of Education, \\ College of Environment, Hohai University, Nanjing 210098, China; Ln1371447351@163.com (N.L.); \\ 201305020041@hhu.edu.cn (S.J.); cx15733927580@163.com (X.C.) \\ * Correspondence: mgflora@hhu.edu.cn; Tel.: +86-13852293249
}

check for updates

Citation: Wang, Y.; Li, N.; Jiang, S.; Chen, X. Application of Extraction and Determination Based on Deep Eutectic Solvents in Different Types of Environmental Samples. Water 2022, 14, 46. https://doi.org/ $10.3390 / w 14010046$

Academic Editor: Donghai Wu

Received: 22 November 2021

Accepted: 22 December 2021

Published: 25 December 2021

Publisher's Note: MDPI stays neutral with regard to jurisdictional claims in published maps and institutional affiliations.

Copyright: (C) 2021 by the authors. Licensee MDPI, Basel, Switzerland. This article is an open access article distributed under the terms and conditions of the Creative Commons Attribution (CC BY) license (https:// creativecommons.org/licenses/by/ $4.0 /)$.

\begin{abstract}
Water sources are an indispensable resource for human survival. Monitoring the pollution status of the surrounding environment is necessary to protect water sources. Research on the environmental matrix of deep eutectic solvents (DESs) has expanded rapidly because of their high extraction efficiency for various target analytes, controllable synthesis, and versatile structure. Following the synthesis of hydrophobic deep eutectic solvents (HDESs), their application in aqueous matrices broadened greatly. The present review conducted a survey on the pollutant extraction methods based DESs in environmental matrices from two aspects, application methods and matrix types; discussed the potential risk of DESs to the environment and future development trends; and provided some references for researchers to choose DES-based extraction methods for environmental research.
\end{abstract}

Keywords: deep eutectic solvents; drinking water; environmental analysis; sample preparation; green solvents

\section{Introduction}

New pollutants continue to appear with the development of society, many of which cannot be decomposed in natural water as a source of drinking water [1]. The pollution process of these pollutants in water sources is slow and hidden. They enter the human body through drinking water and pose a threat to human health. In addition to the production and life of human beings, pollutants in water sources migrate from contaminated soil and the atmosphere into water bodies [2,3]. These pollutants have now been detected in environmental matrices, such as surface water, sewage/sludge, soil/sediments, and indoor air/dust. In order to further study their potential threat, the first step is to understand their occurrence in environmental samples. However, the matrices are complex, and the organic pollutant concentration is usually low to the nanogram level. Therefore, it is urgent to explore an effective pretreatment method.

At present, the main pretreatment method is SPE, but it has disadvantages such as high cost, complicated operation, and poor repeatability. Although LPME overcomes the shortcomings of traditional pretreatment technologies, these methods have disadvantages such as toxic and harmful solvents and poor biodegradability. Based on the concept of green chemistry, Abbott et al. proposed a new type of green solvent called DES [4]. According to the definition, DES is a liquid, and its melting point is lower than all its components. The reason is that hydrogen bonds are formed between the components. Due to their noteworthy properties, such as negligible vapor pressure, large polarity range, and high thermal stability, DESs have been applied in separation processes, analytical chemistry, synthesis, electrochemistry, etc. [5-8]. DES synthesis methods include heating, evaporation, and freeze-drying. The heating method is currently the most commonly used method due to its easy operation [9]. Some authors have developed alternative synthesis methods to make DESs greener. For example, Gomez et al. [10] developed an MA method with a short synthesis time (20 s) and low energy consumption. 
Analytical sample pretreatment is one of the emerging applications of DESs. Due to their properties such as low cost, easy preparation and restructuring, and low toxicity and biodegradability, DESs are preferable over conventional solvents. Additionally, interactions between DESs and target analytes, including electrostatic, $\pi-\pi$, van der Waals (dispersion), hydrogen bonding, hydrophobic, and dipole-dipole and ion-dipole forces, provide DESs with high solubility to pollutants during pretreatment [11]. In addition, the density of DESs is usually higher than water, which helps them separate from the water phase during the extraction process. Thus, the number of reports on using DESs as extractants to concentrate analytes has increased rapidly since 2012 (Figure 1) [5]. DESs have been applied in various pretreatment techniques to extract different kinds of analytes (such as metal ions, fatty and organic acids, volatile organic compounds, dyes and pigments, pesticides, peptides and proteins, plant compounds) in real matrices, including water, air, soil, and biological samples [9].
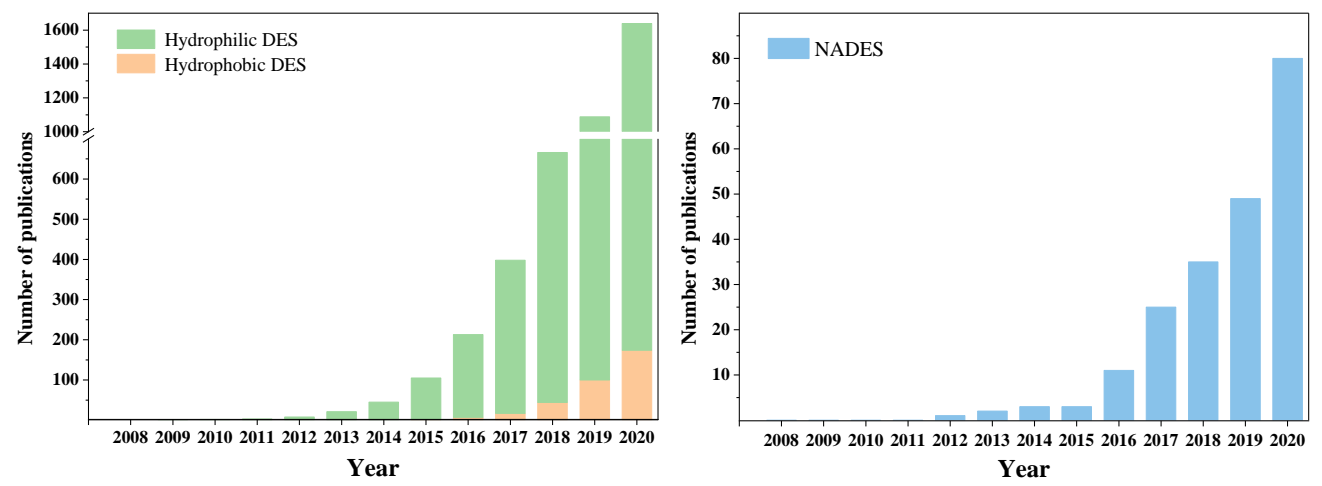

Figure 1. Number of papers published during 2008-2020 in Web of Science (Keywords: "deep eutectic solvents", "hydrophobic deep eutectic solvents", and "nature deep eutectic solvents" with "extraction").

With the increasing application of DESs in the analytical field, many review articles have been published. For example, the review article by Makoś et al. [12] focused on HDESs used in the microextraction method. The review article by Santana et al. [9] compiled two aspects, sample preparation and analytical techniques, related to the application of DESs in analytical chemistry in 2016-2020. A recent review by Tang et al. [13] paid attention to the development of DES-based microextraction procedures. Some recent papers gave a focused and comprehensive review of the applications of DESs during DLLME of pesticides in food samples [14] and coastal zone environmental samples [15]. This review systematically focused on recent applications of DESs in different environmental matrices to improve the general understanding of the use of DESs in analytical chemistry.

\section{Deep Eutectic Solvents}

\subsection{Classification of DESs}

DESs are commonly classified into four types: Type I (quaternary salt and metal halide), Type II (quaternary salt and hydrated metal halide), Type III (quaternary salt, terpene, and hydrogen bond donor), and Type IV (metal halide and HBD) (Figure 2). 


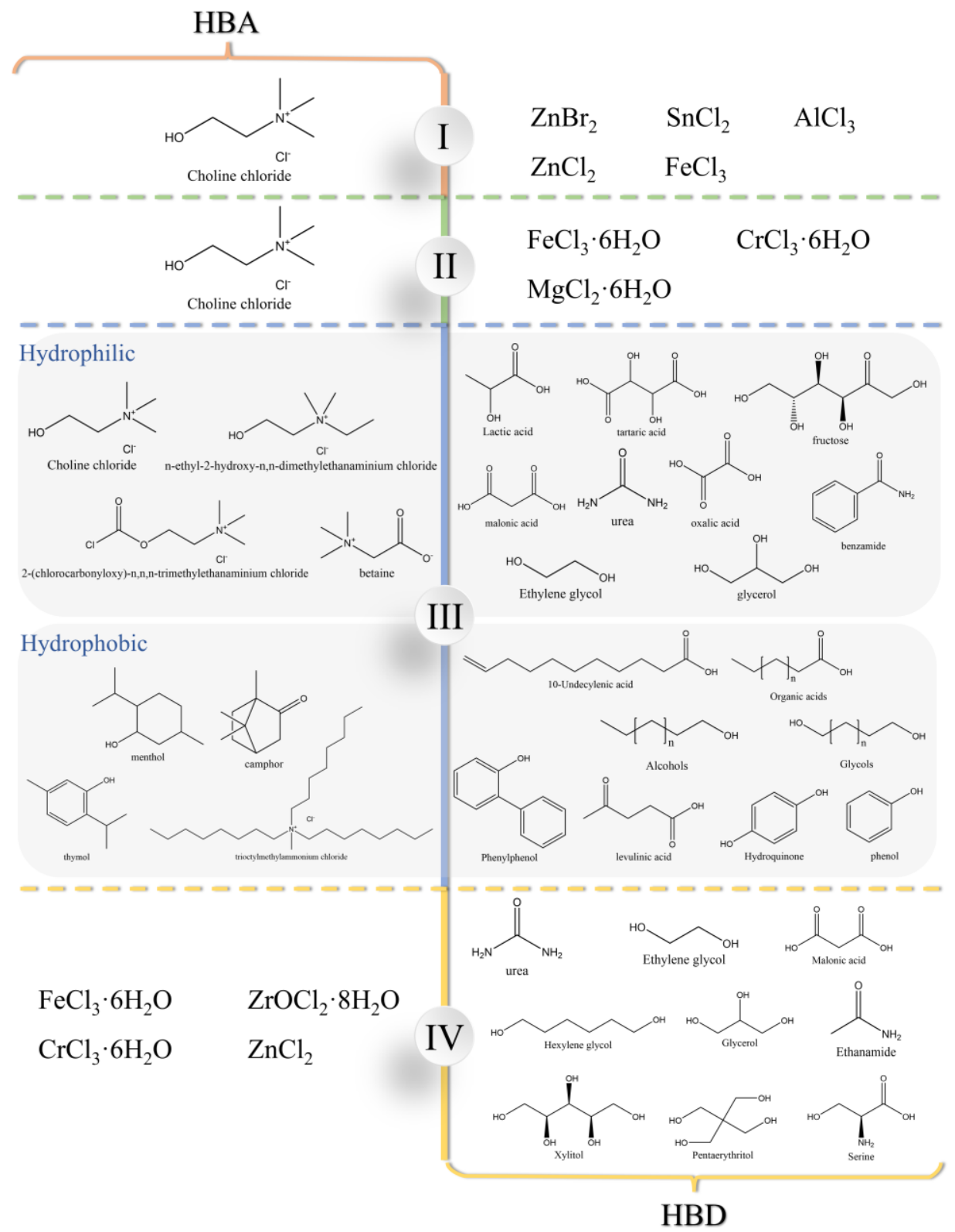

Figure 2. Classification of DESs according to their composition.

Type I DESs are formed by quaternary ammonium salts and nonhydrated metal halides. Although the types of nonhydrated metal halides that can form type I DESs are limited, DESs vary with the molar fraction of nonhydrated metal halides, which is different from ionic liquids consisting of independent anions such as $\mathrm{BF}_{4}^{-}$and $\mathrm{PF}_{6}^{-}$. This kind of ionic DES is mainly used as a catalyst or to synthesize catalysts in the organic field [16].

Type II DESs are formed by quaternary salt and hydrated metal halide. Due to their low cost and insensitivity to components, they are easy to synthesize. However, only a few applications in extraction are available because of the toxicity of metal halide. Choi et al. [17] developed an efficient lipid extraction method from Chlorella vulgaris using a DES composed of [EMIM][OAc] and $\mathrm{FeCl}_{3} \cdot 6 \mathrm{H}_{2} \mathrm{O}$.

Type III DESs formed by quaternary salt or terpene with HBD are fundamentally different from the former two types of DES. In type III DESs, the halogen anion $X^{-}$forms a hydrogen bond with ligand $Y$, which reduces the Coulomb force between the anion and cation. Thus, these DESs possess excellent dissolution properties owing to their ability to donate protons or accept electrons to form hydrogen bonds [18]. Regarding 
environmental analysis, it has been successfully applied to extract and isolate organic compounds, inorganic analytes, pharmaceuticals, pesticides, and so on [9].

Moreover, DESs prepared from a combination of metal halide, generally with transition metals, and organic ligands (HBD) are classified as Type IV [19]. This kind of DES is usually used as an electroplating solution [20] in metal electroplating and a catalyst [21] in organic reactions. Liu et al. [22] used a DES catalyst to convert cellulose into gluconic acid.

\subsection{Hydrophilic and Hydrophobic DESs}

The presence of hydrophilic functional groups in the components, such as hydroxyl, carboxyl, or amino groups, will cause DESs to become hydrophilic (namely hydrophilic DESs), such as Type I, II, IV, and some Type III hydrophilic DESs. The application range of hydrophilic DESs is limited due to their instability in water. Conversely, hydrophilic DESs have great advantages in the extraction of hydrophilic analytes from nonaqueous samples. For example, phenolic compounds are extracted from a variety of plant samples [23-27], and bioactive carbohydrates, such as polysaccharides [28,29] and pectin [30], are extracted from plants. Although most bioactive compounds are hydrophilic, some lipid-soluble bioactive compounds are hydrophobic. Hydrophobic solvents can enhance the extraction efficiency of lipid-soluble bioactive compounds.

To expand the application of DESs, especially in aqueous samples, van Osch et al. [31] proposed the first HDESs in 2015, which consisted of decanoic acid and long-chain quaternary ammonium salt. Later, a series of HDESs composed of a variety of fatty alcohols and long-chain fatty acids combined with long-alkyl-chain quaternary ammonium salts were synthesized [31]. Ribeiro et al. [32] proposed another type of hydrophobic deep eutectic solvent consisting of DL-menthol as the HBA, which is a natural monoterpene, and several short-chain acids (i.e., acetic, lactic, and pyruvic acids) as the HBD. Other terpenes can also be used to synthesize HDESs, such as thymol [33], camphor [34], and lidocaine [35]. However, the presence of hydrophilic components will reduce the stability of HDESs. The extent of influence on stability depends on the hydrophilicity of the components. It is worth highlighting that although there is a leaching loss, the HDES-rich phase still exists independently [12]. HDESs can be used to extract compounds in various matrices, such as artemisinin from leaves [36], cannabinoids from raw cannabis plant [37], pesticides [38] and antibiotics from water [39], drugs from human urine [40], and endocrine disruptor compounds from water [41].

\subsection{Toxicity of DES}

Few reports on the potential toxicity of DESs are available. Generally, DESs synthesized from sugars, alcohols, sugar alcohols, and amides are more eco-friendly, while, in contrast, DESs synthesized from metal ions and organic acids are not "green" [42]. Studies have shown that $\mathrm{ChCl}$-based DESs combined with urea, glycerine, triethylene glycol, and ethylene glycol have no toxic effect, but they do have cytotoxicity. The cytotoxicity of these DESs is higher than their components [43]. Recently, different test organisms were used to test the toxicity of ChCl-based DESs composed of organic acid and sugar. DESs combined with organic acid and sugar had higher cytotoxicity than those combined with organic alcohol. However, the cytotoxicity of the components of the tested DESs was higher than that of DESs [44]. In addition, the molar ratio of HBA and HBD, lipophilicity, and the Hofmeister effect can also affect the toxicity of DESs [45]. Recently, Torregrosa-Crespo et al. [46] proposed that it is more accurate to confine the discussion to a certain concentration range for the toxicity of DESs. Some studies used predictive computational models to evaluate the cytotoxicity of DESs $[42,47,48]$. However, the results from toxicity tests are even more convincing, and more factors need to be considered, including culture conditions, type of culture media, and sterilization methods [46]. In future research avenues, more types of test organisms should be considered to represent different functional levels. It can help us fully understand how aquatic ecosystems are affected by DESs. Moreover, in order to have 
a more comprehensive understanding of the environmental sustainability of DESs, more studies focusing on bioaccumulation and biodegradability are required.

\section{Application Forms in Environmental Analysis}

LLE is the process of separating and extracting components of liquid mixtures with solvents. The volume of the extractant is usually the same as the volume of the water sample. The type of DES used is determined based on the nature of the sample and analyte. Some studies have applied this method to the extraction of volatile organic acids, metal ions, and organic pollutants in environmental water samples. However, LLE is gradually replaced by LPME due to the large volume of organic solvents and poor enrichment effect (Table 1).

LPME is an extraction technology that greatly reduces the volume of the extractant compared with LLE. Many methods have been developed to assist the extraction process, such as vortex, heating, microwave, and ultrasonic. Some studies made the methods more convenient and faster by reducing the number of steps, such as the synthesis of DESs [49,50]. At the same time, in order to more thoroughly separate the organic phase and the water sample, researchers made the extractant magnetic and combined it with LPME [51]. The analyte selectivity of DESs is higher than ordinary organic solvents such as methanol, acetonitrile, and dichloromethane because of the special structure of DESs. Combined with LPME, the method not only has the advantages of extraction technology but also reduces costs and improves environmental friendliness. In general, LPME can be divided into three categories: DLLME, SDME, and HF-LPME. 
Table 1. Extraction technique combined with DESs in environmental analysis.

\begin{tabular}{|c|c|c|c|c|c|c|c|c|c|c|}
\hline \multirow{2}{*}{ Techniques } & \multicolumn{4}{|c|}{ DES } & \multicolumn{2}{|c|}{ Sample } & \multirow{2}{*}{ Other Features } & \multirow{2}{*}{ Analytes } & \multirow{2}{*}{$\begin{array}{l}\text { Instrumental } \\
\text { Analysis }\end{array}$} & \multirow{2}{*}{ LOD (ug/L,g) } \\
\hline & HBA & HBD & Molar Ratio & Volume & Type & Volume & & & & \\
\hline SLLE [52] & N8881-Cl & $\begin{array}{l}\text { Octanol/octanoic } \\
\text { acid }\end{array}$ & $1: 2: 3$ & $2 \mathrm{~mL}$ & Plant leaves & $0.2 \mathrm{~g}$ & $\begin{array}{l}\text { Two DES phases were } \\
\text { involved }\end{array}$ & $\begin{array}{c}\text { Flavonoids } \\
\text { Terpene trilactones } \\
\text { Procyanidin } \\
\text { Polyprenyl } \\
\text { acetates }\end{array}$ & HPLC-UV & \\
\hline LLE [53] & Menthol & Dodecanoic acid & $2: 1$ & & Water & & & $\begin{array}{c}\text { Lower alcohols } \\
\text { Ethanol } \\
\text { 1-Propanol } \\
\text { 1-Butanol }\end{array}$ & NMR & \\
\hline LLE [54] & Dodecanoic acid & $\begin{array}{l}\text { Octanoic acid } \\
\text { Nonanoic acid } \\
\text { Decanoic acid }\end{array}$ & $\begin{array}{l}1: 3 \\
1: 3 \\
1: 2\end{array}$ & $2 \mathrm{~mL}$ & Water & $2 \mathrm{~mL}$ & & Bisphenol A & UV-vis & \\
\hline DLLME [55] & $\mathrm{N} 8881-\mathrm{Cl}$ & Oleic acid & $1: 2$ & $20 \mathrm{uL}$ & $\begin{array}{l}\text { Water and } \\
\text { biological } \\
\text { samples }\end{array}$ & $5 \mathrm{~mL}$ & Vortex assisted & Nitrite & HPLC-UV & 0.2 \\
\hline DLLME [56] & $\begin{array}{c}\text { Quaternary } \\
\text { ammonium salt }\end{array}$ & DL-menthol & & & Aqueous samples & & Air assisted & Benzophenone & HPLC-UV & \\
\hline DLLME [57] & $\mathrm{ChCl}$ & Triethylamine & 1:1 & & $\begin{array}{l}\text { Biological and } \\
\text { environmental } \\
\text { samples }\end{array}$ & $20 \mathrm{~mL}$ & $\begin{array}{c}\text { Air assisted } \\
\text { Volume of } \\
\text { DES/triethylamine } \\
\text { (TEA) (1:1) is } 100 \mathrm{uL} .\end{array}$ & Heavy Metals & FAAS & $0.31-0.99$ \\
\hline DLLME [58] & $\mathrm{ChCl}$ & Phenol & 1:3 & $450 \mathrm{uL}$ & Lake water & $10 \mathrm{~mL}$ & Ultrasound assisted & $\begin{array}{l}\text { Chromium } \\
\text { (III/VI) }\end{array}$ & FAAS & 5.5 \\
\hline DLLME [59] & $\mathrm{ChCl}$ & Phenol & 1:3 & $1000 \mathrm{uL}$ & $\begin{array}{l}\text { Soil, sediment, } \\
\text { and water }\end{array}$ & $25 \mathrm{~mL}$ & Ultrasound assisted & Arsenic & ETAAS & 0.01 \\
\hline DLLME [60] & $\mathrm{N} 4444-\mathrm{Cl}$ & Decanoic acid & $1: 2$ & $200 \mathrm{uL}$ & $\begin{array}{c}\text { Liver } \\
\text { samples }\end{array}$ & $10 \mathrm{~mL}$ & $\begin{array}{l}\text { Ultrasound assisted } \\
\text { DES (ChCl-lactic acid) } \\
\text { is digestion solution }\end{array}$ & Copper & MS-FAAS & 4.00 \\
\hline HS-SDME [61] & N4444-Br & Dodecanol & $1: 2$ & $1.5 \mathrm{uL}$ & $\begin{array}{c}\text { Plant } \\
\text { samples }\end{array}$ & $50 \mathrm{mg}$ & & Terpenes & GC-MS & $0.87-86.40$ \\
\hline HF-LPME [62] & $\mathrm{ChCl}$ & Phenylethanol & 1:4 & $40 \mathrm{uL}$ & $\begin{array}{l}\text { Human plasma } \\
\text { urine and } \\
\text { pharmaceutical } \\
\text { wastewater }\end{array}$ & $10 \mathrm{~mL}$ & $\begin{array}{c}\text { Three-phase } \\
\text { (liquid-liquid-liquid) } \\
\text { microextraction }\end{array}$ & $\begin{array}{c}\text { Antiarrhythmic } \\
\text { agents } \\
\text { Propranolol } \\
\text { Carvedilol } \\
\text { Verapamil } \\
\text { Amlodipine }\end{array}$ & HPLC-UV & \\
\hline
\end{tabular}

N8881-Cl: trioctylmethylammonium chloride (TAC); MS-FAAS: microsample injection system coupled with flame atomic absorption spectrometer; HS-SDME: headspace single-drop microextraction; SLLE: supported liquid-liquid extraction. 


\subsection{DLLME}

In DLLME, the extractant is dispersed by the dispersive solvent or other auxiliary means to form small droplets, which are evenly distributed in the entire solution to increase the contact area. Using DESs as extractants in DLLME can obtain better application prospects [63]. Liu et al. [64] used the DES-DLLME method combined with HPLC-UV to determine SAs in river water. However, hydrophilic DESs cannot exist stably in water, and they can only be used for nonaqueous samples because water can break the hydrogen bond. Therefore, HDESs that use long-chain fatty acids, quaternary amine salts, and terpenes as HBD are applied as extractants for water samples. For example, Werner [65] established the UA-DES-DLLME method for the green and efficient determination of aromatic amines from environmental water samples. El-Deen et al. [66] extracted steroids in a water sample through tetrabutylammonium bromide/acetic acid DES. Wang et al. [67] evaluated the in situ applicability of HDESs for the extraction of UV filters dissolved in raw water samples by DLLME. A new type of DLLME is AA-LLME. By pumping and injecting several times, the extractant and water can be completely mixed. Lamei et al. [68] extracted methadone from biological and water samples using this technique.

\section{2. $S D M E$}

SDME has been recognized as one of the simple miniaturized sample preparation tools for the isolation and preconcentration of several analytes from a complex sample matrix [69]. The application of DESs in SDME is rapidly growing in analytical practice for the extraction and preconcentration of several analytes, owing to their unique physicochemical and mechanical properties [70]. In SDME, droplets are commonly immersed in the sample. In addition, the method of suspending extractant droplets on the tip of a syringe to extract volatile compounds is called HS-SDME.

Yousefi et al. [71] used gel prepared from DES as an extractant in HS-SDME to concentrate volatile hydrocarbons from water and urine samples. Compared with traditional solvents, DESs have higher thermal stability, higher viscosity, lower volatility, and adjustable miscibility and are more capable of forming stable droplets of HS-SDME. A novel DES based on montmorillonite clay, $\mathrm{Fe}_{3} \mathrm{O}_{4}$-DL-menthol, and decanoic acid [51] is highly hydrophobic, with lower viscosity and density than that of water, and can extract explosive compounds from water and soil samples. Deep eutectic solvents were synthesized by mixing tetrabutylammonium bromide (HBA) with various alcoholic molecules and $\mathrm{ChCl}$-urea with ChCl-lactic acid at different molar ratios [72] to analyze terpenes based on the HS-SDME method.

\subsection{HF-LPME}

Pedersen-Bjergaard [73] established a new microextraction method in which the extractant exists in the form of a liquid film. In the HF-LPME system, the extraction phase is usually SLM in the hollow fiber, which separates the target compound from the sample and then enters the acceptor phase in the cavity of the hollow fiber.

In 2018, Khatael et al. reported three-phase HF-LPME based on n-dodecane and DESs, which consisted of $\mathrm{ChCl}$ and MTPB as the acceptor phase of steroidal hormones from biological fluids [74]. Rajabi et al. first adopted a completely eco-friendly and high solubility HDES (ChCl/1-phenylethanol) for HF-LPME in biological and environmental samples [62]. In 2021, Pedersen-Bjergaard et al. first reported that a hydrophobic NADES (coumarin/thymol) was used as SLM for electromembrane extraction in a biological fluid sample and almost completely extracted different polar compounds [75]. This paper proved that DESs are very suitable for extraction in the form of SLM.

\section{Applications in Environmental Matrix}

When the analyte concentration is very low and the sample matrix is complex, the most important and unavoidable step in the analytical process is extraction. Choosing the right extractant can more efficiently analyze and determine the environmental matrix. DESs 
are novel, green, and designable solvents with high degradability and low cost. Therefore, the number of studies on the application of DESs in environmental sample preparation methods is rapidly increasing. As shown in Table 2, most methods using HDESs can be used to detect targets in various types of matrices. Hydrophilic DESs are mainly used for the extraction of active substances from plants and are rarely used for soil samples. The reason is that when detecting the content of organic matter in soil, the target substance is first extracted from the soil into the aqueous solution and then enriched and purified. This will also depend on whether the target is hydrophilic or hydrophobic.

Table 2. Compilation of application of DESs in extraction from various types of environmental matrix.

\begin{tabular}{|c|c|c|c|c|c|}
\hline Sample Matrix & Analytes & $\begin{array}{l}\text { DES Composition } \\
\text { (Mole Ratio) }\end{array}$ & $\begin{array}{l}\text { Method of } \\
\text { Extraction }\end{array}$ & $\begin{array}{l}\text { Instrumental } \\
\text { Analysis }\end{array}$ & LODs \\
\hline \multicolumn{6}{|c|}{ Hydrophilic deep eutectic solvents } \\
\hline $\begin{array}{l}\text { Waters (tap, lake, } \\
\text { waste) [58] }\end{array}$ & $\mathrm{Cr}(\mathrm{III} / \mathrm{VI})$ & $\mathrm{ChCl} /$ phenol (1:3) & UALME & FAAS & $5.5 \mathrm{ug} / \mathrm{L}$ \\
\hline Switchgrass [76] & $\begin{array}{l}\text { Cellulose-rich } \\
\text { pulp, lignin, and } \\
\text { xylose-rich liquor. }\end{array}$ & $\mathrm{ChCl} /$ glycerol (1:2) & & $\begin{array}{l}\text { HPLC-RID, NMR, } \\
\text { ATR-FTIR, XRD }\end{array}$ & \\
\hline $\begin{array}{c}\text { Tartary } \\
\text { buckwheat } \\
\text { Hulls [77] }\end{array}$ & Flavonoid (rutin) & $\mathrm{ChCl} /$ glycerol (1:1) & UAME & HPLC-UV & \\
\hline $\begin{array}{c}\text { Flower petals } \\
\text { [78] }\end{array}$ & Anthocyanins & $\begin{array}{l}\text { Lactic acid/glucose } \\
\text { 1,2-propanediol/ChCl }\end{array}$ & UAE & HPLC-DAD & \\
\hline Soil samples [79] & $\begin{array}{c}\text { As, } \mathrm{Cr}, \mathrm{Mo}, \mathrm{Sb}, \mathrm{Se} \\
\text { and V }\end{array}$ & $\mathrm{ChCl} /$ oxalic acid & UAE & ICP-OES & $0.009-0.1 \mathrm{ug} / \mathrm{g}$ \\
\hline $\begin{array}{c}\text { Sediment } \\
\text { samples [80] }\end{array}$ & $\mathrm{Cu}$ & $\begin{array}{c}\mathrm{ChCl} \text { /oxalic acid } \\
(1.5: 1)\end{array}$ & SLE & ICP-OES & $1.2 \mathrm{ug} / \mathrm{L}$ \\
\hline \multicolumn{6}{|c|}{ Hydrophobic deep eutectic solvents } \\
\hline $\begin{array}{c}\text { Wastewater and } \\
\text { human plasma } \\
\text { [81] }\end{array}$ & $\begin{array}{l}\text { Amphetamine- } \\
\text { type } \\
\text { stimulants }\end{array}$ & $\begin{array}{c}\mathrm{ChCl} / \text { phenylethanol } \\
(1: 4)\end{array}$ & AA-EME & HPLC-UV & $2.0-5.0 \mathrm{ng} / \mathrm{mL}$ \\
\hline $\begin{array}{c}\text { Surface water } \\
\text { [49] }\end{array}$ & Fluoroquinolones & $\begin{array}{c}\text { Thymol/Heptanoic } \\
\text { acid }(2: 1)\end{array}$ & In situ LPME & HPLC-UV & $3 \mathrm{ng} / \mathrm{mL}$ \\
\hline Wastewater [82] & Neonicotinoids & $\begin{array}{l}\text { DL-menthol/organic } \\
\text { acids }\end{array}$ & LLE & UV-vis & \\
\hline River water [56] & $\begin{array}{l}\text { BP, BP-1, BP-3, } \\
\text { ВР-6, 4OH-BP }\end{array}$ & $\begin{array}{c}\text { DL-menthol/decanoic } \\
\text { acid (1:1) }\end{array}$ & $\begin{array}{l}\text { Air-assisted } \\
\text { DLLME }\end{array}$ & HPLC-DAD & $0.05-0.2 \mathrm{ng} / \mathrm{mL}$ \\
\hline $\begin{array}{l}\text { Water and soil } \\
\text { samples [51] }\end{array}$ & Explosives & $\begin{array}{l}\text { DL-menthol/decanoic } \\
\text { acid (1:2) }\end{array}$ & $\begin{array}{l}\text { Ferrofluid-based } \\
\text { LPME }\end{array}$ & HPLC-UV & $\begin{array}{c}0.22-0.91 \\
0.01-0.04 \mathrm{mg} / \mathrm{mL}\end{array}$ \\
\hline Soil samples [83] & Nitrotoluene & Borneol/menthol & MSPD & HPLC-UV & $0.12-0.33 \mathrm{ug} / \mathrm{g}$ \\
\hline $\begin{array}{l}\text { Water, soil, egg } \\
\text { yolk samples [84] }\end{array}$ & Insecticide & $\begin{array}{c}\mathrm{N} 4444-\mathrm{Br} / \text { decanoic } \\
\text { acid }\end{array}$ & DLLME & HPLC-UV & $0.001-0.003 \mathrm{ug} / \mathrm{mL}$ \\
\hline $\begin{array}{l}\text { Water, and } \\
\text { biological } \\
\text { samples [55] }\end{array}$ & Nitrite & $\begin{array}{l}\text { N8851-Cl/oleic acid } \\
(1: 2)\end{array}$ & $\begin{array}{l}\text { Vortex-assisted } \\
\text { DLLME }\end{array}$ & HPLC-UV & $0.2 \mathrm{ng} / \mathrm{mL}$ \\
\hline $\begin{array}{l}\text { Biological and } \\
\text { indoor air } \\
\text { sample [85] }\end{array}$ & Formaldehyde & $\begin{array}{c}\text { N8851-Cl/4- } \\
\text { cyanophenol } \\
(1: 1)\end{array}$ & VA-LLME & HPLC-DAD & $0.2 \mathrm{ng} / \mathrm{mL}$ \\
\hline
\end{tabular}

AA-EME: air agitated-emulsification microextraction; MSPD: matrix solid-phase dispersion.

\subsection{Extraction from Aqueous Samples}

For aqueous applications, HDESs are desirable due to their stability in aqueous solution. HDESs are mainly divided into two categories according to the type of HBA/tetraalkylquaternary-ammonium-based HDESs and terpene-based HDESs. Quaternary-ammoniumbased HDESs can extract metals. Ruggeri et al. [86] investigated HDESs based on tetrabutylammonium chloride and decanoic acid and their application in the extraction of $\mathrm{Cr}(\mathrm{VI})$ species from an aqueous phase. In addition to extracting inorganic metal ions, this type of HDES can also be used to extract a variety of organic substances. Yousefi et al. [87] 
prepared a HDES consisting of TBAB and carboxylic acids and applied the synthesized HDES in the analysis of PAHs in environmental water samples. Terpene-based HDESs have also been applied to extract various organic analytes by liquid-liquid extraction. In 2015, HDESs consisting of DL-menthol (HBA) and various organic acids (HBD) were first reported [32]. Lower alcohols, ethanol, propanol, and butanol could be enriched in mentholbased HDESs [53]. In addition, the extraction of inorganic metals has been reported, and In [88] and $\mathrm{Cu}$ [89] can be transferred to menthol and thymol-based HDESs [89].

For aqueous samples, hydrophilic DESs are generally not advisable as the extractant phase for aqueous matrices unless other organic solvents (THF) are added to ensure phase separation. This will reduce the greenness of the method since the volume of organic solvents is increased. However, it should be noted that the efficiency of extracting watersoluble analytes will be significantly improved when a hydrophilic DES is used as the extractant. One of the most widely used hydrophilic DESs for the extraction of contaminants in aqueous samples is formed by $\mathrm{ChCl}$ and phenol in different molar ratios. In this case, the mixture of DES and water makes necessary the use of an emulsifier (aprotic solvent) that achieves phase separation because of the self-aggregation phenomenon. Some studies used choline chloride/phenol DES as an extractant and an aprotic solvent THF to separate microcystin [90], BTRs, and BTs [91] from surface water samples. Sometimes, the role of DES in the extraction process is not as an extractant but as an assistant agent to extract steroids from river and tap water [66].

\subsection{Extraction from Air Samples and Soil/Sediment Samples}

Most applications of DESs in air samples are used as absorption solutions for $\mathrm{CO}_{2}$, $\mathrm{SO}_{2}$, and NO [92]. However, only a few DESs have been used for the extraction and determination of analytes from air samples up to now. HDESs have been used as extractants using aqueous acid as an absorption solution in the VA-LLME method coupled with HPLC for the selective enrichment and indirect determination of formaldehyde from indoor air samples [85]. In the extraction and separation of analytes from solid samples, the choice of DES is not limited by its own hydrophilicity and hydrophobicity. Therefore, the choice of DES only depends on the solubility of contaminants in the DES when used as an extractant. Following the extraction of solid samples, the suspensions obtained by centrifugation usually need to be filtered before entering the instrument for analysis. The DES composed of choline chloride and oxalic acid was used as a solvent for extraction of $\mathrm{As}, \mathrm{Cr}, \mathrm{Mo}, \mathrm{Sb}, \mathrm{Se}$, and V in real soil samples [79] and $\mathrm{Cu}$ in sediment samples [80]. Compared with the results determined using the conventional acid digestion method, the method was found to be accurate, precise, and eco-friendly. In addition, it can also be used for the extraction and determination of organic pollutants from soil such as pesticides [84] and nitrotoluene [83]. Furthermore, some studies use DESs to prepare ferrofluid to extract explosives from soil samples by suspended droplet microextraction [51]. The extraction procedure has a high potential for application in complex matrices.

\subsection{Extraction from Organism Samples}

Compared to environmental water, soil/sediment, and air, the extraction of biological samples based on DES is less explored. In applications related to the field of biological sample analysis, according to the sample classification, it can be divided into three different types: biological fluid, animal, and plant samples. Works related to biological samples mainly focus on digestion methods based on DESs, for example: determination of $\mathrm{Cu}, \mathrm{Zn}$, and Fe in fish samples [93]; $\mathrm{Cu}, \mathrm{Fe}, \mathrm{Ni}$ and $\mathrm{Zn}$ in marine biological samples [94]; As, $\mathrm{Ca}$, $\mathrm{Cd}, \mathrm{Cu}, \mathrm{Fe}, \mathrm{K}, \mathrm{Mg}, \mathrm{Mn}, \mathrm{Na}, \mathrm{P}$, and $\mathrm{Zn}$ in plants [95]; and polycyclic aromatic hydrocarbons in biological samples [96]. In general, various methods have been applied in the extraction of biological samples, such as heating [93] and microwave [94].

The air-assisted DLLME method was used to determine trace amphetamine and methamphetamine in human plasma [81]. HDESs consisting of $\mathrm{ChCl}$ and phenylethanol were used as the extraction medium during this microextraction process. Rastbood et al. [97] 
proposed $\mathrm{ChCl:EG@SiO}{ }_{2} @ \mathrm{Fe}_{3} \mathrm{O}_{4}$ ferrofluid as a sorbent for the magnetic SPME of the antiinflammatory drug meloxicam from human plasma and urine samples.

It is interesting to note that the application of DESs in plant samples to extract natural active substances and natural pigments from the herbaceous plant safflower is more stable in NADESs than in water [98]. Recently, Dai et al. [78] employed diverse NADESs to extract anthocyanins from the purple and orange petals of Catharanthus roseus. Cao et al. [52] suggested a two-phase DES system to extract and fractionate analytes of diverse polarity, i.e., hydrophobic polyprenyl acetates and partially hydrophilic components (flavonoids, terpene trilactones, and procyanidin) from ginkgo leaves. Compared with the traditional acid digestion method, the reagent consumption of the DES-based extraction method is greatly reduced, the required time is shorter, and the method is safer because neither high pressure nor concentrated acid is involved.

\section{Concluding Remarks}

To control the pollution of drinking water sources, it is necessary not only to conduct real-time detection of water samples in water sources but also to pay certain attention to the nearby soil and atmosphere $[99,100]$. Extraction is an important and unavoidable step in the environmental analysis process. DESs are ideal as extractants because of their combination of simple and cost-effective preparation and task-specific design to meet the needs of specific processes. Extraction based on DESs is a reliable analytical tool with wide potential applications in environmental analysis. This review summarized recent studies of DESs used in environment samples and briefly discussed the extraction modes and types of environmental matrices, which is beneficial for researchers to understand DES applications in environmental matrices.

Although DESs have been widely applied in the field of extraction and separation, several challenges in DES-based extractants remain. Some DESs are composed of substances with suspicious toxicity. Compared with a single component, the toxicity of the combination of toxic and nontoxic compounds cannot be confirmed [46]. In order to use DESs more safely in extraction technology, toxicity and the environmental impact of more types of DESs need to be further studied. Another problem with HDESs is that although people are more and more interested in the synthesis of HDESs, their number is still limited, and further efforts are needed to synthesize new HDESs as extractants [101]. Furthermore, the study of the physicochemical properties of DESs during the synthesis and extraction mechanism also needs more attention because research on DESs is still at the application level, and the changes in the microstructure and physical and chemical properties are not clear [102]. Structural-related studies need to be designed to be more accurately applied to different environmental samples. In the future, the great interest of many researchers will promote the more sustainable development of extraction technology using DESs.

Author Contributions: Conceptualization, Y.W.; data curation, N.L.; methodology, N.L.; software, S.J. and X.C.; writing—original draft preparation, Y.W.; writing-review and editing, N.L.; supervision, Y.W.; project administration, Y.W.; funding acquisition, Y.W. All authors have read and agreed to the published version of the manuscript.

Funding: This research was funded by the Fundamental Research Funds for the Central Universities, B200202105, and the World-Class Universities (Disciplines) and Characteristic Development Guidance Funds for the Central Universities.

Institutional Review Board Statement: Not Applicable.

Informed Consent Statement: Not Applicable.

Data Availability Statement: Not Applicable.

Conflicts of Interest: The authors declare no conflict of interest. 
Abbreviations

\begin{tabular}{|c|c|}
\hline \multicolumn{2}{|l|}{ Abbreviations } \\
\hline AA & Air assisted \\
\hline BTRs & Benzotriazole derivatives \\
\hline BTs & Benzothiazole derivatives \\
\hline $\mathrm{ChCl}$ & Choline chloride \\
\hline DES & Deep eutectic solvent \\
\hline DLLME & Dispersive liquid-liquid microextraction \\
\hline DNA & Deoxyribonucleic acid \\
\hline [EMIM][OAc] & 1-Ethyl-3-methyl imidazolium acetate \\
\hline HBA & Hydrogen bond acceptor \\
\hline HBD & Hydrogen bond donor \\
\hline HDESs & Hydrophobic deep eutectic solvent \\
\hline HF-LPME & Fiber-based liquid-phase microextraction \\
\hline HPLC & High-performance liquid chromatography \\
\hline HS-SDME & Headspace single-drop microextraction \\
\hline LLE & Liquid-liquid extraction \\
\hline LPME & Liquid-phase microextraction \\
\hline MA & Microwave assisted \\
\hline МТРВ & Methyltriphenylphosphonium bromide \\
\hline NADES & Nature deep eutectic solvent \\
\hline PAHs & Polycyclic aromatic hydrocarbons \\
\hline SAs & Sulfonamides \\
\hline SDME & Single-drop microextraction \\
\hline SLM & Supported liquid membrane \\
\hline SPE & Solid-phase extraction \\
\hline SPME & Solid-phase microextraction \\
\hline TBAB & Tetrabutylammonium bromide \\
\hline THF & Tetrahydrofuran \\
\hline UA & Ultrasound-assisted \\
\hline VA-LLME & Vortex-assisted liquid-liquid microextraction \\
\hline Nomenclature & \\
\hline- & Dipole-dipole forces \\
\hline$\rho$ & Density \\
\hline- & Ion-dipole forces \\
\hline $\mathrm{m}_{\mathrm{p}}$ & Melting point \\
\hline$S^{r}$ & Solubility \\
\hline- & Polarity \\
\hline$\eta$ & Viscosity \\
\hline- & van der Waals (dispersion) forces \\
\hline . & $\pi-\pi$ forces \\
\hline
\end{tabular}

\section{References}

1. Acosta-Rodríguez, I.; Rodríguez-Pérez, A.; Pacheco-Castillo, N.; Enríquez-Domínguez, E.; Cárdenas-González, J.; Martínez-Juárez, V.-M. Removal of Cobalt (II) from Waters Contaminated by the Biomass of Eichhornia crassipes. Water 2021, 13, 1725. [CrossRef]

2. $\quad$ Maurya, P.K.; Ali, S.A.; Alharbi, R.S.; Yadav, K.K.; Alfaisal, F.M.; Ahmad, A.; Ditthakit, P.; Prasad, S.; Jung, Y.-K.; Jeon, B.-H. Impacts of Land Use Change on Water Quality Index in the Upper Ganges River near Haridwar, Uttarakhand: A GIS-Based Analysis. Water 2021, 13, 3572. [CrossRef]

3. Rahmawati, R.R.; Putro, A.H.S.; Lee, J.L. Analysis of Long-Term Shoreline Observations in the Vicinity of Coastal Structures: A Case Study of South Bali Beaches. Water 2021, 13, 3527. [CrossRef]

4. Abbott, A.P.; Capper, G.; Davies, D.L.; Rasheed, R.K.; Tambyrajah, V. Novel solvent properties of choline chloride/urea mixtures. Chem. Commun. 2003, 39, 70-71. [CrossRef] [PubMed]

5. Tang, B.; Zhang, H.; Row, K.H. Application of deep eutectic solvents in the extraction and separation of target compounds from various samples. J. Sep. Sci. 2015, 38, 1053-1064. [CrossRef]

6. Shishov, A.; Bulatov, A.; Locatelli, M.; Carradori, S.; Andruch, V. Application of deep eutectic solvents in analytical chemistry. A review. Microchem. J. 2017, 135, 33-38. [CrossRef] 
7. Ndizeye, N.; Suriyanarayanan, S.; Nicholls, I.A. Polymer synthesis in non-ionic deep eutectic solvents. Polym. Chem. 2019, 10, 5289-5295. [CrossRef]

8. Nkuku, C.A.; LeSuer, R.J. Electrochemistry in Deep Eutectic Solvents. J. Phys. Chem. B 2007, 111, 13271-13277. [CrossRef]

9. Santana-Mayor, Á.; Rodríguez-Ramos, R.; Herrera-Herrera, A.V.; Socas-Rodríguez, B.; Rodríguez-Delgado, M. Ángel Deep eutectic solvents. The new generation of green solvents in analytical chemistry. TrAC Trends Anal. Chem. 2021, 134, 116108. [CrossRef]

10. Gomez, F.J.V.; Espino, M.; Fernández, M.A.; Silva, M.F. A Greener Approach to Prepare Natural Deep Eutectic Solvents. Chem. 2018, 3, 6122-6125. [CrossRef]

11. Faraji, M. Novel hydrophobic deep eutectic solvent for vortex assisted dispersive liquid-liquid micro-extraction of two auxins in water and fruit juice samples and determination by high performance liquid chromatography. Microchem. J. 2019, 150, 104130. [CrossRef]

12. Makoś, P.; Słupek, E.; Gębicki, J. Hydrophobic deep eutectic solvents in microextraction techniques-A review. Microchem. J. 2020, 152, 104384. [CrossRef]

13. Tang, W.; An, Y.; Row, K.H. Emerging applications of (micro) extraction phase from hydrophilic to hydrophobic deep eutectic solvents: Opportunities and trends. TrAC Trends Anal. Chem. 2021, 136, 116187. [CrossRef]

14. Musarurwa, H.; Tavengwa, N.T. Deep eutectic solvent-based dispersive liquid-liquid micro-extraction of pesticides in food samples. Food Chem. 2021, 342, 127943. [CrossRef]

15. Wang, Y.; Li, J.; Sun, D.; Yang, S.; Liu, H.; Chen, L. Strategies of dispersive liquid-liquid microextraction for coastal zone environmental pollutant determination. J. Chromatogr. A 2021, 1658, 462615. [CrossRef] [PubMed]

16. Qin, H.; Hu, X.; Wang, J.; Cheng, H.; Chen, L.; Qi, Z. Overview of acidic deep eutectic solvents on synthesis, properties and applications. Green Energy Environ. 2020, 5, 8-21. [CrossRef]

17. Choi, S.-A.; Lee, J.-S.; Oh, Y.-K.; Jeong, M.-J.; Kim, S.W.; Park, J.-Y. Lipid extraction from Chlorella vulgaris by molten-salt/ionicliquid mixtures. Algal Res. 2014, 3, 44-48. [CrossRef]

18. Abbott, A.P.; Frisch, G.; Hartley, J.; Ryder, K.S. Processing of metals and metal oxides using ionic liquids. Green Chem. 2011, 13, 471-481. [CrossRef]

19. Abbott, A.P.; Barron, J.C.; Ryder, K.; Wilson, D. Eutectic-Based Ionic Liquids with Metal-Containing Anions and Cations. Chem. Eur. J. 2007, 13, 6495-6501. [CrossRef]

20. Abbott, A.P.; Al-Barzinjy, A.A.; Abbott, P.D.; Frisch, G.; Harris, R.C.; Hartley, J.; Ryder, K.S. Speciation, physical and electrolytic properties of eutectic mixtures based on $\mathrm{CrCl} 3 \cdot 6 \mathrm{H} 2 \mathrm{O}$ and urea. Phys. Chem. Chem. Phys. 2014, 16, 9047-9055. [CrossRef]

21. Shahabi, D.; Tavakol, H. One-pot synthesis of quinoline derivatives using choline chloride/tin (II) chloride deep eutectic solvent as a green catalyst. J. Mol. Liq. 2016, 220, 324-328. [CrossRef]

22. Liu, F.; Xue, Z.; Zhao, X.; Mou, H.; He, J.; Mu, T. Catalytic deep eutectic solvents for highly efficient conversion of cellulose to gluconic acid with gluconic acid self-precipitation separation. Chem. Commun. 2018, 54, 6140-6143. [CrossRef] [PubMed]

23. Meng, Z.; Zhao, J.; Duan, H.; Guan, Y.; Zhao, L. Green and efficient extraction of four bioactive flavonoids from Pollen Typhae by ultrasound-assisted deep eutectic solvents extraction. J. Pharm. Biomed. Anal. 2018, 161, 246-253. [CrossRef] [PubMed]

24. Yin, X.-S.; Zhong, Z.-F.; Bian, G.-L.; Cheng, X.-J.; Li, D.-Q. Ultra-rapid, enhanced and eco-friendly extraction of four main flavonoids from the seeds of Oroxylum indicum by deep eutectic solvents combined with tissue-smashing extraction. Food Chem. 2020, 319, 126555. [CrossRef] [PubMed]

25. El Kantar, S.; Rajha, H.N.; Boussetta, N.; Vorobiev, E.; Maroun, R.G.; Louka, N. Green extraction of polyphenols from grapefruit peels using high voltage electrical discharges, deep eutectic solvents and aqueous glycerol. Food Chem. 2019, 295, 165-171. [CrossRef]

26. Ali, M.C.; Chen, J.; Zhang, H.; Li, Z.; Zhao, L.; Qiu, H. Effective extraction of flavonoids from Lycium barbarum L. fruits by deep eutectic solvents-based ultrasound-assisted extraction. Talanta 2019, 203, 16-22. [CrossRef]

27. Ozturk, B.; Parkinson, C.; Gonzalez-Miquel, M. Extraction of polyphenolic antioxidants from orange peel waste using deep eutectic solvents. Sep. Purif. Technol. 2018, 206, 1-13. [CrossRef]

28. Nie, J.; Chen, D.; Lu, Y. Deep Eutectic Solvents Based Ultrasonic Extraction of Polysaccharides from Edible Brown Seaweed Sargassum horneri. J. Mar. Sci. Eng. 2020, 8, 440. [CrossRef]

29. Gao, C.; Cai, C.; Liu, J.; Wang, Y.; Chen, Y.; Wang, L.; Tan, Z. Extraction and preliminary purification of polysaccharides from Camellia oleifera Abel. seed cake using a thermoseparating aqueous two-phase system based on EOPO copolymer and deep eutectic solvents. Food Chem. 2020, 313, 126164. [CrossRef]

30. Shafie, M.H.; Yusof, R.; Gan, C.-Y. Deep eutectic solvents (DES) mediated extraction of pectin from Averrhoa bilimbi: Optimization and characterization studies. Carbohydr. Polym. 2019, 216, 303-311. [CrossRef]

31. van Osch, D.J.; Zubeir, L.F.; Bruinhorst, A.V.D.; Rocha, M.A.; Kroon, M.C. Hydrophobic deep eutectic solvents as water-immiscible extractants. Green Chem. 2015, 17, 4518-4521. [CrossRef]

32. Ribeiro, B.D.; Florindo, C.; Iff, L.C.; Coelho, M.A.Z.; Marrucho, I. Menthol-based Eutectic Mixtures: Hydrophobic Low Viscosity Solvents. ACS Sustain. Chem. Eng. 2015, 3, 2469-2477. [CrossRef]

33. Martins, M.A.R.; Crespo, E.A.; Pontes, P.V.A.; Silva, L.P.; Bülow, M.; Maximo, G.J.; Batista, E.A.C.; Held, C.; Pinho, S.P.; Coutinho, J.A.P. Tunable Hydrophobic Eutectic Solvents Based on Terpenes and Monocarboxylic Acids. ACS Sustain. Chem. Eng. 2018, 6, 8836-8846. [CrossRef] 
34. Makoś, P.; Przyjazny, A.; Boczkaj, G. Hydrophobic deep eutectic solvents as "green" extraction media for polycyclic aromatic hydrocarbons in aqueous samples. J. Chromatogr. A 2018, 1570, 28-37. [CrossRef]

35. van Osch, D.J.G.P.; Parmentier, D.; Dietz, C.H.J.T.; Bruinhorst, A.V.D.; Tuinier, R.; Kroon, M.C. Removal of alkali and transition metal ions from water with hydrophobic deep eutectic solvents. Chem. Commun. 2016, 52, 11987-11990. [CrossRef]

36. Cao, J.; Yang, M.; Cao, F.; Wang, J.; Su, E. Well-Designed Hydrophobic Deep Eutectic Solvents As Green and Efficient Media for the Extraction of Artemisinin from Artemisia annua Leaves. ACS Sustain. Chem. Eng. 2017, 5, 3270-3278. [CrossRef]

37. Křižek, T.; Bursová, M.; Horsley, R.; Kuchař, M.; Tuma, P.; Čabala, R.; Hložek, T. Menthol-based hydrophobic deep eutectic solvents: Towards greener and efficient extraction of phytocannabinoids. J. Clean. Prod. 2018, 193, 391-396. [CrossRef]

38. Paul, N.; Naik, P.K.; Ribeiro, B.D.; Pattader, P.S.G.; Marrucho, I.M.; Banerjee, T. Molecular Dynamics Insights and Water Stability of Hydrophobic Deep Eutectic Solvents Aided Extraction of Nitenpyram from an Aqueous Environment. J. Phys. Chem. B 2020, 124, 7405-7420. [CrossRef]

39. Florindo, C.; Lima, F.; Branco, L.C.; Marrucho, I.M. Hydrophobic Deep Eutectic Solvents: A Circular Approach to Purify Water Contaminated with Ciprofloxacin. ACS Sustain. Chem. Eng. 2019, 7, 14739-14746. [CrossRef]

40. Shishov, A.; Chislov, M.; Nechaeva, D.; Moskvin, L.; Bulatov, A. A new approach for microextraction of non-steroidal antiinflammatory drugs from human urine samples based on in-situ deep eutectic mixture formation. J. Mol. Liq. 2018, 272, 738-745. [CrossRef]

41. Florindo, C.; Monteiro, N.V.; Ribeiro, B.D.; Branco, L.; Marrucho, I. Hydrophobic deep eutectic solvents for purification of water contaminated with Bisphenol-A. J. Mol. Liq. 2020, 297, 111841. [CrossRef]

42. Bystrzanowska, M.; Tobiszewski, M. Assessment and design of greener deep eutectic solvents-A multicriteria decision analysis. J. Mol. Liq. 2021, 321, 114878. [CrossRef]

43. Hayyan, M.; Hashim, M.A.; Hayyan, A.; Al-Saadi, M.A.; AlNashef, I.M.; Mirghani, M.E.; Saheed, O.K. Are deep eutectic solvents benign or toxic? Chemosphere 2013, 90, 2193-2195. [CrossRef]

44. Radošević, K.; Zeleznjak, J.; Bubalo, M.C.; Redovniković, I.R.; Slivac, I.; Srček, V.G. Comparative in vitro study of cholinium-based ionic liquids and deep eutectic solvents toward fish cell line. Ecotoxicol. Environ. Saf. 2016, 131, 30-36. [CrossRef]

45. Wen, Q.; Chen, J.-X.; Tang, Y.-L.; Wang, J.; Yang, Z. Assessing the toxicity and biodegradability of deep eutectic solvents. Chemosphere 2015, 132, 63-69. [CrossRef] [PubMed]

46. Torregrosa-Crespo, J.; Marset, X.; Guillena, G.; Ramón, D.J.; Martínez-Espinosa, R.M. New guidelines for testing “Deep eutectic solvents" toxicity and their effects on the environment and living beings. Sci. Total Environ. 2020, 704, 135382. [CrossRef] [PubMed]

47. Macário, I.; Oliveira, H.; Menezes, A.C.; Ventura, S.; Pereira, J.L.; Gonçalves, A.M.M.; Coutinho, J.; Gonçalves, F.J.M. Cytotoxicity profiling of deep eutectic solvents to human skin cells. Sci. Rep. 2019, 9, 3932. [CrossRef] [PubMed]

48. Macário, I.P.; Jesus, F.; Pereira, J.L.; Ventura, S.P.; Gonçalves, A.M.; Coutinho, J.A.; Gonçalves, F.J. Unraveling the ecotoxicity of deep eutectic solvents using the mixture toxicity theory. Chemosphere 2018, 212, 890-897. [CrossRef]

49. Li, K.; Jin, Y.; Jung, D.; Park, K.; Kim, H.; Lee, J. In situ formation of thymol-based hydrophobic deep eutectic solvents: Application to antibiotics analysis in surface water based on liquid-liquid microextraction followed by liquid chromatography. J. Chromatogr. A 2020, 1614, 460730. [CrossRef] [PubMed]

50. Ge, D.; Wang, Y.; Jiang, Q.; Dai, E. A Deep Eutectic Solvent as an Extraction Solvent to Separate and Preconcentrate Parabens in Water Samples Using in situ Liquid-Liquid Microextraction. J. Braz. Chem. Soc. 2019, 30, 1203-1210. [CrossRef]

51. Zarei, A.R.; Nedaei, M.; Ghorbanian, S.A. Ferrofluid of magnetic clay and menthol based deep eutectic solvent: Application in directly suspended droplet microextraction for enrichment of some emerging contaminant explosives in water and soil samples. J. Chromatogr. A 2018, 1553, 32-42. [CrossRef]

52. Cao, J.; Chen, L.; Li, M.; Cao, F.; Zhao, L.; Su, E. Two-phase systems developed with hydrophilic and hydrophobic deep eutectic solvents for simultaneously extracting various bioactive compounds with different polarities. Green Chem. 2018, 20, 1879-1886. [CrossRef]

53. Verma, R.; Banerjee, T. Liquid-Liquid Extraction of Lower Alcohols Using Menthol-Based Hydrophobic Deep Eutectic Solvent: Experiments and COSMO-SAC Predictions. Ind. Eng. Chem. Res. 2018, 57, 3371-3381. [CrossRef]

54. Florindo, C.; Romero, L.; Rintoul, I.; Branco, L.C.; Marrucho, I.M. From Phase Change Materials to Green Solvents: Hydrophobic Low Viscous Fatty Acid-Based Deep Eutectic Solvents. ACS Sustain. Chem. Eng. 2018, 6, 3888-3895. [CrossRef]

55. Zhang, K.; Li, S.; Liu, C.; Wang, Q.; Wang, Y.; Fan, J. A hydrophobic deep eutectic solvent-based vortex-assisted dispersive liquid-liquid microextraction combined with HPLC for the determination of nitrite in water and biological samples. J. Sep. Sci. 2019, 42, 574-581. [CrossRef] [PubMed]

56. Ge, D.; Zhang, Y.; Dai, Y.; Yang, S. Air-assisted dispersive liquid-liquid microextraction based on a new hydrophobic deep eutectic solvent for the preconcentration of benzophenone-type UV filters from aqueous samples. J. Sep. Sci. 2018, 41, 1635-1643. [CrossRef]

57. Ezoddin, M.; Lamei, N.; Siami, F.; Abdi, K.; Karimi, M.A. Deep Eutectic Solvent Based Air Assisted Ligandless Emulsification Liquid-Liquid Microextraction for Preconcentration of Some Heavy Metals in Biological and Environmental Samples. Bull. Environ. Contam. Toxicol. 2018, 101, 814-819. [CrossRef] 
58. Yilmaz, E.; Soylak, M. Ultrasound assisted-deep eutectic solvent based on emulsification liquid phase microextraction combined with microsample injection flame atomic absorption spectrometry for valence speciation of chromium(III/VI) in environmental samples. Talanta 2016, 160, 680-685. [CrossRef]

59. Zounr, R.A.; Tuzen, M.; Khuhawar, M.Y. Ultrasound assisted deep eutectic solvent based on dispersive liquid liquid microextraction of arsenic speciation in water and environmental samples by electrothermal atomic absorption spectrometry. J. Mol. Liq. 2017, 242, 441-446. [CrossRef]

60. Kanberoglu, G.S.; Yilmaz, E.; Soylak, M. Usage of deep eutectic solvents for the digestion and ultrasound-assisted liquid phase microextraction of copper in liver samples. J. Iran. Chem. Soc. 2018, 15, 2307-2314. [CrossRef]

61. Triaux, Z.; Petitjean, H.; Marchioni, E.; Boltoeva, M.; Marcic, C. Deep eutectic solvent-based headspace single-drop microextraction for the quantification of terpenes in spices. Anal. Bioanal. Chem. 2020, 412, 933-948. [CrossRef] [PubMed]

62. Rajabi, M.; Ghassab, N.; Hemmati, M.; Asghari, A. Highly effective and safe intermediate based on deep eutectic medium for carrier less-three phase hollow fiber microextraction of antiarrhythmic agents in complex matrices. J. Chromatogr. B 2019, 1104, 196-204. [CrossRef]

63. Wu, B.; Guo, Z.; Li, X.; Huang, X.; Teng, C.; Chen, Z.; Jing, X.; Zhao, W. Analysis of pyrethroids in cereals by HPLC with a deep eutectic solvent-based dispersive liquid-liquid microextraction with solidification of floating organic droplets. Anal. Methods 2021, 13, 636-641. [CrossRef] [PubMed]

64. Liu, L.; Zhu, T. Emulsification liquid-liquid microextraction based on deep eutectic solvents: An extraction method for the determination of sulfonamides in water samples. Anal. Methods 2017, 9, 4747-4753. [CrossRef]

65. Werner, J. Novel deep eutectic solvent-based ultrasounds-assisted dispersive liquid-liquid microextraction with solidification of the aqueous phase for HPLC-UV determination of aromatic amines in environmental samples. Microchem. J. 2020, $153,104405$. [CrossRef]

66. El-Deen, A.K.; Shimizu, K. Deep eutectic solvent as a novel disperser in dispersive liquid-liquid microextraction based on solidification of floating organic droplet (DLLME-SFOD) for preconcentration of steroids in water samples: Assessment of the method deleterious impact on the environment using Analytical Eco-Scale and Green Analytical Procedure Index. Microchem. J. 2019, 149, 103988. [CrossRef]

67. Wang, H.; Xu, Q.; Jiao, J.; Wu, H. A solidified floating organic drop-dispersive liquid-liquid microextraction based on in situ formed fatty acid-based deep eutectic solvents for the extraction of benzophenone-UV filters from water samples. New J. Chem. 2021, 45, 14082-14090. [CrossRef]

68. Lamei, N.; Ezoddin, M.; Abdi, K. Air assisted emulsification liquid-liquid microextraction based on deep eutectic solvent for preconcentration of methadone in water and biological samples. Talanta 2017, 165, 176-181. [CrossRef]

69. Kailasa, S.K.; Koduru, J.R.; Park, T.J.; Singhal, R.K.; Wu, H.-F. Applications of single-drop microextraction in analytical chemistry: A review. Trends Environ. Anal. Chem. 2021, 29, e00113. [CrossRef]

70. Farooq, M.Q.; Zeger, V.R.; Anderson, J.L. Comparing the extraction performance of cyclodextrin-containing supramolecular deep eutectic solvents versus conventional deep eutectic solvents by headspace single drop microextraction. J. Chromatogr. A 2021, 1658, 462588. [CrossRef]

71. Yousefi, S.M.; Shemirani, F.; Ghorbanian, S.A.; Ali, S. Enhanced headspace single drop microextraction method using deep eutectic solvent based magnetic bucky gels: Application to the determination of volatile aromatic hydrocarbons in water and urine samples. J. Sep. Sci. 2017, 41, 966-974. [CrossRef]

72. Abbasi-Ahd, A.; Shokoufi, N.; Kargosha, K. Headspace single-drop microextraction coupled to microchip-photothermal lens microscopy for highly sensitive determination of captopril in human serum and pharmaceuticals. Microchim. Acta 2017, 184, 2403-2409. [CrossRef]

73. Pedersen-Bjergaard, S.; Rasmussen, K.E. Liquid-Liquid-Liquid Microextraction for Sample Preparation of Biological Fluids Prior to Capillary Electrophoresis. Anal. Chem. 1999, 71, 2650-2656. [CrossRef]

74. Khataei, M.M.; Yamini, Y.; Nazaripour, A.; Karimi, M. Novel generation of deep eutectic solvent as an acceptor phase in threephase hollow fiber liquid phase microextraction for extraction and preconcentration of steroidal hormones from biological fluids. Talanta 2018, 178, 473-480. [CrossRef]

75. Hansen, F.A.; Santigosa-Murillo, E.; Ramos-Payán, M.; Muñoz, M.; Øiestad, E.L.; Pedersen-Bjergaard, S. Electromembrane extraction using deep eutectic solvents as the liquid membrane. Anal. Chim. Acta 2021, 1143, 109-116. [CrossRef]

76. Chen, Z.; Reznicek, W.D.; Wan, C. Deep eutectic solvent pretreatment enabling full utilization of switchgrass. Bioresour. Technol. 2018, 263, 40-48. [CrossRef] [PubMed]

77. Huang, Y.; Feng, F.; Jiang, J.; Qiao, Y.; Wu, T.; Voglmeir, J.; Chen, Z.-G. Green and efficient extraction of rutin from tartary buckwheat hull by using natural deep eutectic solvents. Food Chem. 2017, 221, 1400-1405. [CrossRef]

78. Dai, Y.; Rozema, E.; Verpoorte, R.; Choi, Y.H. Application of natural deep eutectic solvents to the extraction of anthocyanins from Catharanthus roseus with high extractability and stability replacing conventional organic solvents. J. Chromatogr. A 2016, 1434, 50-56. [CrossRef] [PubMed]

79. Matong, J.M.; Nyaba, L.; Nomngongo, P.N. Determination of As, Cr, Mo, Sb, Se and V in agricultural soil samples by inductively coupled plasma optical emission spectrometry after simple and rapid solvent extraction using choline chloride-oxalic acid deep eutectic solvent. Ecotoxicol. Environ. Saf. 2017, 135, 152-157. [CrossRef] 
80. Bağda, E.; Altundağ, H.; Tüzen, M.; Soylak, M. A Novel Selective Deep Eutectic Solvent Extraction Method for Versatile Determination of Copper in Sediment Samples by ICP-OES. Bull. Environ. Contam. Toxicol. 2017, 99, 264-269. [CrossRef]

81. Rajabi, M.; Ghassab, N.; Hemmati, M.; Asghari, A. Emulsification microextraction of amphetamine and methamphetamine in complex matrices using an up-to-date generation of eco-friendly and relatively hydrophobic deep eutectic solvent. J. Chromatogr. A 2018, 1576, 1-9. [CrossRef]

82. Florindo, C.; Branco, L.; Marrucho, I. Development of hydrophobic deep eutectic solvents for extraction of pesticides from aqueous environments. Fluid Phase Equilibria 2017, 448, 135-142. [CrossRef]

83. Nedaei, M.; Zarei, A.R.; Ghorbanian, S.A. Miniaturized matrix solid-phase dispersion based on deep eutectic solvent and carbon nitride associated with high-performance liquid chromatography: A new feasibility for extraction and determination of trace nitrotoluene pollutants in soil samples. J. Chromatogr. A 2019, 1601, 35-44. [CrossRef] [PubMed]

84. Kachangoon, R.; Vichapong, J.; Santaladchaiyakit, Y.; Burakham, R.; Srijaranai, S. An Eco-Friendly Hydrophobic Deep Eutectic Solvent-Based Dispersive Liquid-Liquid Microextraction for the Determination of Neonicotinoid Insecticide Residues in Water, Soil and Egg Yolk Samples. Molecules 2020, 25, 2785. [CrossRef] [PubMed]

85. Zhang, K.; Liu, C.; Li, S.; Fan, J. A hydrophobic deep eutectic solvent based vortex-assisted liquid-liquid microextraction for the determination of formaldehyde from biological and indoor air samples by high performance liquid chromatography. $J$. Chromatogr. A 2019, 1589, 39-46. [CrossRef]

86. Ruggeri, S.; Poletti, F.; Zanardi, C.; Pigani, L.; Zanfrognini, B.; Corsi, E.; Dossi, N.; Salomäki, M.; Kivelä, H.; Lukkari, J.; et al. Chemical and electrochemical properties of a hydrophobic deep eutectic solvent. Electrochimica Acta 2019, 295, 124-129. [CrossRef]

87. Yousefi, S.M.; Shemirani, F.; Ghorbanian, S.A. Hydrophobic Deep Eutectic Solvents in Developing Microextraction Methods Based on Solidification of Floating Drop: Application to the Trace HPLC/FLD Determination of PAHs. Chromatographia 2018, 81, 1201-1211. [CrossRef]

88. Tereshatov, E.E.; Boltoeva, M.Y.; Folden, C.M. First evidence of metal transfer into hydrophobic deep eutectic and low-transitiontemperature mixtures: Indium extraction from hydrochloric and oxalic acids. Green Chem. 2016, 18, 4616-4622. [CrossRef]

89. Schaeffer, N.; Martins, M.A.R.; Neves, C.M.S.S.; Pinho, S.P.; Coutinho, J.A.P. Sustainable hydrophobic terpene-based eutectic solvents for the extraction and separation of metals. Chem. Commun. 2018, 54, 8104-8107. [CrossRef]

90. Chen, Y.-C.; Ao, Y.-T.; Ding, W.-H. Determination of microcystins in water samples by deep eutectic solvent-based vortex-assisted liquid-liquid microextraction coupled with ultrahigh-performance liquid chromatography-high resolution mass spectrometry. RSC Adv. 2019, 9, 38669-38676. [CrossRef]

91. Ao, Y.-T.; Chen, Y.-C.; Ding, W.-H. Deep eutectic solvent-based ultrasound-assisted emulsification microextraction for the rapid determination of benzotriazole and benzothiazole derivatives in surface water samples. J. Hazard. Mater. 2021, $401,123383$. [CrossRef] [PubMed]

92. Shishov, A.; Pochivalov, A.; Nugbienyo, L.; Andruch, V.; Bulatov, A. Deep eutectic solvents are not only effective extractants. TrAC Trends Anal. Chem. 2020, 129, 115956. [CrossRef]

93. Habibi, E.; Ghanemi, K.; Fallah-Mehrjardi, M.; Dadolahi-Sohrab, A. A novel digestion method based on a choline chloride-oxalic acid deep eutectic solvent for determining $\mathrm{Cu}, \mathrm{Fe}$, and $\mathrm{Zn}$ in fish samples. Anal. Chim. Acta 2013, 762, 61-67. [CrossRef] [PubMed]

94. Ghanemi, K.; Navidi, M.-A.; Fallah-Mehrjardi, M.; Dadolahi-Sohrab, A. Ultra-fast microwave-assisted digestion in choline chloride-oxalic acid deep eutectic solvent for determining $\mathrm{Cu}, \mathrm{Fe}, \mathrm{Ni}$ and $\mathrm{Zn}$ in marine biological samples. Anal. Methods 2014, 6, 1774-1781. [CrossRef]

95. Santana, A.P.; Andrade, D.F.; Vargas, J.A.M.; Amaral, C.; de Oliveira, A.P.; Gonzalez, M.H. Natural deep eutectic solvents for sample preparation prior to elemental analysis by plasma-based techniques. Talanta 2019, 199, 361-369. [CrossRef]

96. Helalat-Nezhad, Z.; Ghanemi, K.; Fallah-Mehrjardi, M. Dissolution of biological samples in deep eutectic solvents: An approach for extraction of polycyclic aromatic hydrocarbons followed by liquid chromatography-fluorescence detection. J. Chromatogr. A 2015, 1394, 46-53. [CrossRef]

97. Rastbood, S.; Hadjmohammadi, M.R.; Majidi, S.M. Development of a magnetic dispersive micro-solid-phase extraction method based on a deep eutectic solvent as a carrier for the rapid determination of meloxicam in biological samples. Anal. Methods 2020, 12, 2331-2337. [CrossRef] [PubMed]

98. Dai, Y.; Verpoorte, R.; Choi, Y.H. Natural deep eutectic solvents providing enhanced stability of natural colorants from safflower (Carthamus tinctorius). Food Chem. 2014, 159, 116-121. [CrossRef] [PubMed]

99. Song, M.; Jiang, Y.; Liu, Q.; Tian, Y.; Liu, Y.; Xu, X.; Kang, M. Catchment versus Riparian Buffers: Which Land Use Spatial Scales Have the Greatest Ability to Explain Water Quality Changes in a Typical Temperate Watershed? Water 2021, 13, 1758. [CrossRef]

100. Vorobyev, S.; Kolesnichenko, Y.; Korets, M.; Pokrovsky, O. Testing Landscape, Climate and Lithology Impact on Carbon, Major and Trace Elements of the Lena River and Its Tributaries during a Spring Flood Period. Water 2021, 13, 2093. [CrossRef]

101. Cunha, S.C.; Fernandes, J.O. Extraction techniques with deep eutectic solvents. TrAC Trends Anal. Chem. 2018, 105, 225-239. [CrossRef]

102. Liang, X.; Zhu, Y.; Qi, B.; Li, S.; Luo, J.; Wan, Y. Structure-property-performance relationships of lactic acid-based deep eutectic solvents with different hydrogen bond acceptors for corn stover pretreatment. Bioresour. Technol. 2021, 336, 125312. [CrossRef] [PubMed] 